\title{
Postmodern Tüketici Özelliklerinin Marka Sadakatine Etkisi
}

\author{
Niyazi Gümüș ${ }^{*}$ Ebru Onurlubaşs* \\ * Dr. Öğr. Üyesi, Bolu Abant İzzet Baysal Üniversitesi Bolu MYO, Bolu / Türkiye \\ E-Posta: niyazigumus@ibu.edu.tr \\ ORCID: $\underline{0000-0001-8737-3114}$ \\ ** Doçent Dr, Trakya Üniversitesi, Keşan Yusuf Çapraz UBY, Edirne / Türkiye \\ E-Posta: ebruonurlubas@trakya.edu.tr \\ ORCID: $\underline{0000-0002-2341-0788}$
}

Öz

Postmodernizm sanattan spora, mimariden kültüre, günlük yaşama varnncaya kadar her alanda etkisini gösteren bir olgudur. En fazla etkilediği alanların başında ise pazarlama ve tüketim gelmektedir. Postmodernizm ile birlikte tüketim faaliyeti salt insan ihtiyaçlarının karşılanmasından çok daha öte bir anlama bürünmüştür. Günümüzde ürünler somut değerlerinden daha çok sembolik değerleri nedeniyle satın alınır hale gelmiştir. Bu nedenle pazarlama alanında özellikle postmodern tüketici en çok konuşulan başlıklar arasında öne çıkmaya başlamıştır. Tüketici davranışlarında meydana gelen değişimlere ek olarak tüketicilerin bir de postmodern özellikler taşıması marka ve firmaların işini daha da zorlaştırmaktadır. Bu nedenle araştırmanın amacı markalar için son derece önemli olan sadık müşteri oluşturma sürecinde postmodern tüketici özelliklerinin etkisinin incelenmesi olarak belirlenmiştir. Bu amaç doğrultusunda postmodern tüketici özelliklerine sahip olduğu düşünülen üniversite öğrencilerinden oluşan 308 tüketici ile yüz yüze anket yapılmış ve veriler toplanmıştır. Elde edilen verilere ilk olarak AMOS programıyla Doğrulayıcı Faktör Analizi uygulanmıştır. Araştırma sonucunda postmodern tüketici özelliklerinden gerçeküstücülük boyutunun marka sadakati üzerinde etkisi olduğu, diğer iki boyutun etkisinin olmadı̆̆ tespit edilmiştir.

Anahtar Kelimeler: Postmodern tüketici, marka sadakati, tüketici davranışları. 


\title{
The Effect of Postmodern Consumer Characteristics on Brand Loyalty
}

\begin{abstract}
Postmodernism is a phenomenon that shows its effect in every field from art to sports, architecture to culture and daily life. With postmodernism, consumer activity has become much more than just meeting human needs. Nowadays, products have become symbolic values rather than concrete values. Therefore, especially in the field of marketing, the postmodern consumer has started to stand out among the most talked about topics. In addition to the changes in consumer behavior, the postmodern characteristics of consumers also make it more difficult for brands and firms. Therefore, the aim of the research is to investigate the effect of postmodern consumer characteristics in the process of creating loyal customers which are very important for brands. For this purpose, face-to-face surveys were conducted with 308 consumers of university students who were thought to have postmodern consumer characteristics and data were collected. First of all, Confirmatory Factor Analysis was applied with AMOS program. As a result of the research, it has been determined that surrealism dimension, which is one of the postmodern consumer characteristics, has an effect on brand loyalty and the other two dimensions do not.
\end{abstract}

Keywords: Postmodern consumer, brand loyalty, consumer behavior. 


\section{Giriş}

Tüketim insanoğlunun var olduğu günden bu yana gerçekleştirdiği faaliyetlerin başında gelmektedir. Çünkü insanoğlu yaşamsal faaliyetlerini sürdürebilmek için tüketmek zorundadır. Zaman içinde üretim teknolojilerinde meydana gelen gelişmeler kitlesel üretimi ortaya çkarmış ve her alanda büyük bir bolluk çağı yaşanmaya başlanmıştır. Üretimde meydana gelen kitlesel üretim, gelirde ortaya çıan iyileşmeler, bilgi ve iletişim teknolojileri ile birlikte iletişim ve etkileşimin kolaylaşması ve hızlanması beraberinde tüketim kavramına yüklenen anlamda da değişiklikleri getirmiştir. Bireyler artık hızla değiş(tiril)en koşullara ayak uydurabilmek adına daha fazla ve daha hızlı tüketme yarışına girmişlerdir. Bu hızlı tüketme yarışı bireyleri tükettikleri ürünlerin içeriğinden daha çok sembolik değerlerine dikkat eder hale getirmiştir. Dolayısı ile artık bireyler için ne tükettiğinden daha çok nerede, nasıl, kiminle, ne kadar tükettiği önemli hale gelmiştir. Şüphesiz bireylerin tüketim şekillerinin değişmesinde yeni medya olarak ifade edilen sosyal medya mecralarının hızla akan sayfalarında, hızla paylaşılan görsellerin de etkisinin olduğunu unutmamak gerekir. Tüketicilerin içinde bulunduğu bu sembolik ağırlıklı tüketim postmodernizmin bir yansıması olarak değerlendirilmektedir. Genel olarak bakıldığında günümüzde bireylerin tüketime yükledikleri anlamın değiştiği ve tüketicilerin satın alma kararlarının postmodern kültürün etkisi ile şekillendiği gözlenmektedir.

Bu kapsamda bu araştırma ile postmodern tüketici özelliklerinin marka sadakat davranışlarına etkisinin araştırılması amaçlanmıştır. Bu amaç kapsaminda öncelikle postmodernizm kavramı, postmodern tüketici kavramı ve özellikleri ile literatürde yer alan postmodern tüketicilerin tüketim alışkanlıkları ile ilgili çalışmalar ele alınmıştır.

\section{Postmodernizm}

İlk olarak edebiyat ve mimari alanlarında ortaya çıan postmodernizm esas olarak kendini İkinci Dünya Savaşı'ndan sonra göstermeye başlamıştır. Özellikle 1980'li yıllarda postmodernizm konusu üzerine yapılan araştırmalar hız kazanmıştır. Fakat postmodernizm kavramının tanımı açısından fikir birliği oluşturulamamıştır. Kavrama zaman zaman yüklenen oldukça 
karmaşık ve zor anlamlar bazen yerini basit anlatımlara bırakmıştır. Doğal olarak tanım üzerinde uzlaşma sağlamak güçleşmiştir. "Postmodernistlerin sayısı kadar postmodern tanım bulunmaktadır diyen Featherstone durumu belki de en iyi şekilde özetleyen kişi olmuştur (Kazancıŏglu, 2019). Bununla birlikte, postmodern kavramı, çoğunlukla geçmişten kopuşu ya da zaman sürecinde kırılmayı ifade edecek bir içerikle kullanılmış ve bu yaklaşım bekleneceği üzere yoğun tartışmaları da beraberinde getirmiştir (Şaylan, 2009).

Postmodernizm, egemen ifadeler veya anlamlara karşı bir başkaldırı hareketi olarak görülmekte ve her türlü bütünleştirici, genelleştirici yaklaşımları reddetmektedir. Postmodernizm, modernizmin hakim olduğu dünyada modernizmin ilerlemeci, kalkınmacı anlayışının insanları baskı altında tuttuğunu düşünerek evrensel ve genel bütün kabullere karşı durmaktadır. $\mathrm{Bu}$ durumda postmodernizm, modernizmin oluşturduğu aydınlanma, bilimsel ve sanayi devrimlerinin ortaya koyduğu kalkınmacı anlayıştan ve bilimsel bilgiye yüklenen kutsallıktan ciddi bir ayrılığı da sembolize etmektedir. Postmodernizm genel geçerlik iddiaları taşıyan meta anlatılarının kabul edilmediği, aksine çoğulculuğun ve parçalanmanın kabul edildiği farklılıkların dışlanmadığı, aksine vurgulandığı, bireyselleşmenin öne çıkartıldığı bir durumu anlatmaktadır (Kırılmaz ve Ayparçası, 2016). Postmodernizm, her bir istekli tüketiciyi, kendisinin bu üretimin (yapımının) belirlenmesinde, katılımcıların hepsinde olduğu gibi belirleyici ve temsil süreçlerinden kaynaklanan mitlerin, anlatıların ve simülasyonların sembolik yapısının belirlenmesinde eşit bir katılıma haline getirme çağrısı olarak görülmektedir (Furat ve Venkatesh, 1995).

Bugün içinde bulunduğumuz postmodern dünyadaki çevremizde malların, hizmetlerin, nesnelerin çoğaltılmasıyla oluşturulmuş ve insanoğlunun ekolojisinde temel bir dönüşüme neden olan akıl almaz bir bolluk ve tüketim gerçekliği yaşanmaktadır. Bütün bu bolluk içerisinde insanlara bakıldığında daha çok nesneler tarafından kuşatılmış oldukları görülmektedir (Baudrillard, 2017). Biriktirme güdüsünün sonucunda oluşan ve bireyi kuşatan bu nesneler ile ilgili olarak özelliklerinin bilinmediği akıllı cep telefonları, statü kaygısıyla alınan otomobiller, genç ve sağlıklı görünebilmek için alınan vitaminler, diyet ürünleri, kişisel bakım ürünleri, kullanılmayan, yazlıklar, devremülkler ve reklamlarda, mağazalarda görüp 
bir kez kullanılıp kenara atılan kıyafetler ilk akla gelen ürünler olmaktadır (Gümüş, 2018).

Sonuç olarak postmodernizmi henüz gerçekleşmiş ve tamamlanmış bir dönüşüm olarak görmek doğru olmayacağ1 gibi, böyle bir dönüşümün başladığın bile söylemek zordur, bunu böyle bir geçişin olabilirliğinin farkında olmak diye yorumlamak belki de daha doğru bir ifade olacaktır (Tekeli, 2017).

\section{Postmodern Tüketici Davranışları}

Postmodernizm ile birlikte her alanda ortaya çıkan parçalanma farklılıkların tolere edilmesini ve özgürleşmeyi beraberinde getirmiştir. Birey bu ortamda birleştirilmiş anlar yerine ayrı ayrı ve farklı anlarda mutlu olmayı tercih etmektedir. Sonuçta pazar; parçalanmış benlik ve hazlardan oluşan anların yaşandığı bir merkez haline dönüşmüştür. Başka bir ifadeyle pazar, pek çok tüketici ve ürün üzerine inşa edilen, ilişkilerin tamamınn geçici olduğu ve her değişim için tüketicinin kapsamlı bir ilişki kurmasının gerekli olmadığı bir yapı görünümüne bürünmüştür. Hatta tüketici alım gücü olduğu sürece deneme satın alımlar yapabilir ve daha sonra üründen vazgeçebilir veya onu geçici olarak kullanarak başka bir ürüne geçiş yapabilir hale dönüşmüştür. Bununla birlikte, tüketicinin sadakat düzeyinde ortaya çıan azalma, pazara dâhil olma alanlarında parçalanmayı beraberinde getirmektedir (Kayaman ve Armutlu, 2003). Firat vd. (1995) postmodern tüketiciyi, büyük projelere olan bağlılığından yoksun ve farklı deneyimler isteyen ve her birini olağanüstü heyecan verici ve eğlenceli bir deneyim haline getirmek için karşılaştı̆̆ farklı durumlarda kendini (pazarlanabilir) bir nesne olarak görmeye istekli biri olarak tanımlamaktadır.

Fırat ve Shultz (2001) postmodern tüketici ile ilgili yaptıkları çalışmalarında postmodern tüketicinin özelliklerini gerçeküstücülük, dağını özne ve çoklu benlik olarak öne çıkarmışlardır. Yazarlar gerçeküstücülük kavramını; güçlü bir anlam ve sosyal gerçeklik oluşumunun koşulu ve aldatıcı ya da simulasyonun temsilleri ile ayn zamanda tüketicinin sosyal kimliğinin inşası süreci olarak tanımlamışlardır. Odabaşı (2004) ise gerçeküstücülük kavramını gerçeküstücülük ya da üstgerçeklik ile gerçek olmayan arasındaki farkın bulanıklaşması olarak ifade etmiştir. İnsanların mevcut gerçeklik yerine sanal gerçeklikte yaşama eğilimleri bunun bir so- 
nucudur. Postmodern bireyin birçok şeyi birlikte aynı anda denemek isteme eğilimi, belki de geçmiş ve geleceğin birlikte denenebileceği algılamasını meydana getirmektedir. Ancak, bu birliktelik kısa süreli olabilecek ve düşlenmiş olan bir deneyimin yaşanması biçiminde kendini gösterecektir. Postmodern birey için önemli olan, sürekli bir güncellik içinde yaşamak, bitmeyen ve sonsuz bugünü aynı gerçekleştirmektir.

Dağını özne ya da öznenin merkezsizleşmesi ile ilgili olarak ise ürün artık sadece bir nesne olarak görülmemektedir. Postmodern bağlamda, insanlar genelde nesneler tarafından kontrol edilir ya da kendileri arzu nesneleri olarak görülür ve diğer insanlar ya da sosyal çevre tarafından tüketilirler. Bu durum özellikle, insan ya da insan vücudunun tüketim nesnesi olarak görüldüğü moda endüstrisinde açık bir şekilde görünür hale gelmektedir (Fırat vd., 1995).

Son olarak çoklu benlik boyutu ise, çağdaş tüketici benliğini etkilediği için tartışlan postmodern koşulların çoğunu ele almaktadır. Parçalanma, yaşamın anlık deneyimlerindeki tüketicinin kendine bağlı parçalanmalarını yansıtmaktadır. Çoğu zaman, karşılaşılan çeşitli durumlarla tam olarak başa çıkma ve bunlarla başa çıkma düzeninin bir parçalanma olmasını ifade etmektedir (Furat ve Schultz, 2001). Postmodern toplumun üyelerinin yaşam tarzlarının ve deneyimlerinin son derece parçalanmış tüketim eylemlerinden doğduğu bilinmektedir. Esas olarak, tüketimle ilgili her eylem, birbiriyle bağlantılı olmayan, birleştirilmemiş ya da ortak bir hedefe yönelik olmayan bölüm serilerinden bir parça olarak algılanmaktadır. Örneğin tv izleme, kahvaltı yapma, haber okuma, çamaşır yıkama, sinemaya, tiyatroya ya da sirke gitme, seyahat etme gibi. Dahası, bütün bu tüketim anları, her birinde farklı bir benlik imajını sergileyebilen tüketicilerin bir çeşit "imajdeğiştirme oyunu olarak ifade edilmektedir (Fırat ve Venkatesh, 1993).

Postmodern tüketici davranışları incelendiğinde bütün seçenekleri kabul ettiğini ve tek bir seçeneğe uymak yerine farklı kimlikler altında sunulabileceğini göstermektedir. Postmodern tüketici, kısaca parçalanmış ve paradoksal tüketim anları yaşayan parçalanmış bir birey olarak görünmektedir (Teschl, 2007; Hamouda ve Gharbi, 2013). Postmodern tüketici; geçmişi ve geleceği, farklı temaları herhangi birine bağlanmadan yaşayarak, deneyim sahibi olmayı istemektedir. Örneğin, turizm faaliyetine katılan tüketiciler, geçmişe ait ve geleceğe ilişkin pek çok deneyimi şuan içinde yaşamayı arzulamaktadırlar. Antalya Belek'te “Dünyanın Harikaları” teması altında inşa 
edilen otel işletmeleri de bu deneyime örnek olarak verilebilecektir (Kayaman ve Armutlu, 2003).

Modern tüketici belirli bir ürün veya hizmetin işlevselliğini, fayda değerini ve bu ürün veya hizmetin "problem" çözme yeteneğine değer verirken postmodern tüketici bunlarla daha az ilgilenmektedir. Postmodern tüketici oldukça dinamik, karmaşık ve parçalanmış bir toplumda bir öz ya da kimlik duygusu yaratmaya odaklanmakta ve sonuç olarak belirli bir ürünün ya da hizmetin projelendirdiği sembolik ya da kültürel değere daha fazla eğilim göstermektedir. Ayrıca postmodern tüketici ürün ya da hizmetin içerik değerinden ziyade içerdiği görüntü değerine daha fazla yoğunlaşmaktadır. $\mathrm{Bu}$ durum modern tüketicilerde bulunan marka sadakatinin postmodern tüketicilerde olmadığını ve pazarda bir rekabet aracı olmayacağını göstermesi açısından önemlidir (Berner ve Tonder, 2003).

Postmodern tüketiciler mal ve hizmetleri sadece fonksiyonlarından dolayı değil, mal ve hizmetlerin imajlarından dolayı satın alıp tüketmektedir. Bu tür tüketimlerin öne çıtığı bir toplumda işaret ya da gösterge ekonomisinden bahsedilmemesi mümkün görünmemektedir. Böyle bir ekonominin ilk özelliği tüketimin önem kazanıp üretime yönlendirmesidir. İkinci özelliği ise, ürünlerin neredeyse birbirinin benzeri haline gelmesinden dolayı farklılıkların sadece imajlar aracılı̆̆ı ile gerçekleşebileceğidir (Odabaşı, 2004). Tüketim yoluyla kendisini ifade etmek isteyen postmodern tüketicilerin beklentilerini anlayabilmek ve bu beklentileri rakiplerden daha etkili bir şekilde karşılayabilmek için pazarlama yöneticilerinin tüketimin sembolik doğasına daha fazla yoğunlaşmaları ve bu tür tüketici kalıplarını anlamaları gerekmektedir. Dolayısıyla pazarlamacıların kendi markalarını rakip markalardan farklılaştırmak amacıyla ürünün sembolik özelliklerini öne çıkartmalarının gerekli olduğunu söylemek yanlış olmayacaktır. Ürün özellikleri çok benzer olsa da sembolik unsurlarla oluşturulan çok küçük farklılıklar tüketicilerin satın alma kararını etkileyebilmektedir (Azizağaoğlu ve Altunışı, 2012).

Postmodernite ile birlikte tüketiciler, ürünlerin kullanım değerinden ziyade kendisi ile başkaları arasında bağ oluşturan anlamlarla daha fazla ilgilenmektedir. Başkalarıyla birlikte tüketmekten değil, onlarla bir araya gelerek paylaştıkları duygulardan tatmin arayan postmodern tüketiciler, ait olmak istedikleri ve kendilerini tanımlayacakları toplulukları seçerek ya da kendileri oluşturarak topluluk bağlarını yeniden kazanmak ve özgürlükle- 
rini bu şekilde ifade etmek istemektedirler. Bu açıdan postmodernizmde tüketiciler, kitlenin artık bir parçası değil, daha çok deneyimler, duygular, inançlar, yaşam tarzları ile birbirine bağlanan parçalanmış grupların üyeleri olarak görülmektedirler (Özbölük, 2015). Bu nedenle pazarlamacilar, tüketicileri bir arada tutabilen, topluluk hissini güçlendiren ve klana üye olma ayrıcalığını destekleyen ürünlere pazarlama çalışmalarında daha çok yer vermelidirler. Artık tahmin edilebilir, büyük, homojen ve durağan tüketici gruplarına yönelik pazarlama stratejileri günümüzde işe yaramamaktadır. Tüketicinin kendini diğerlerinden farklılaştırabileceği, kişiselleştirmeyi mümkün kılan ürünlerin başarısı daha yüksek görülmektedir. Ayrıca ürünlerin pazardaki başarısı, bireyler arasında oluşan sosyal bağların geliştirilmesi ve güçlendirilmesi diğer bir ifade ile ürünlerin bağlayıcı değerlerinin artırılması yoluyla sağlanabilecektir (Kayaman ve Armutlu, 2003). Yukarıda ifade edilen postmodern tüketici özelliklerine ek olarak postmodern tüketici özelliklerini daha iyi anlamaya yardımcı olacak postmodern tüketicilerin hizmetten beklentileri aşağıda özetlenmektedir (Berner ve Tonder, 2003).

- Sahip olduğu kimliğini, tükettiği mal ve hizmetler aracılı̆̆ıla oluşturur. Kimlik oluşturma sürecinde özellikle ürün veya hizmetin maddi olmayan değerleri daha etkilidir. Bu nedenle elde ettiği fonksiyonel değere daha az değer verir. Sonuç olarak, tüm mal veya hizmetleri, yansıttıkları sembolik değerleri açısından değerlendirir.

- Mal ve hizmetlerin tüketimi konusundaki tercihlerinde son derece bireyseldir.

- Herhangi bir mal veya hizmete sadık değildir. Marka sadakatinin üzerindeki baskıya uymaz ve kendi seçtiği veya arzu ettiği yere gitme ve satın alma özgürlügünü kullanmak ister.

- Satın aldığı mal ve hizmetlerde anlık memnuniyeti arar (ihtiyaç duyar) ve dolayısıyla satın aldığı mal ve hizmetlerle ilgili yaşadığı sorularına çözüm ister.

- Gerçeklere odaklanır. Hizmet sağlayıc hizmeti sağlayamazsa, ona güvenini kaybeder ve ihtiyacını karşılayacak başka bir sağlayıcı arayışına girer.

- Bilgi ve bilgi teknolojisi odaklıdır.

- Satın aldığı mal veya hizmetlerden, pazarlama çalışmaları ile sunulandan daha fazlasını bekler. 
- Yüksek oranda uyumsuz değer sistemleriyle birlikte sunulan birçok yaşam tarzına abone olur, takip eder.

- Toplumun geleneksel değerlerine uymaz ve davranış kalıpları öngörülemez.

Yukarıda ifade edilen postmodern tüketici özelliklerine ilave olarak, alışılagelmiş tüketim kalıplarına boyun eğmeyi kabul etmeyen tüketici gruplarının kendi kendilerine yeterli olma mücadelesi olarak görülen gönüllü sadelik bu anlamda bir postmodern tüketici hareketi ve bir postmodern tüketici özelliği olarak algılanmaktadır (Cengiz, 2014). Eroğlu (2016) ise yaptığı araştırmada hedonik tüketim, statü tüketimi, gösteriş̧̧i tüketim, içtepisel satın alma ve moda yönelimli tüketim davranışlarının postmodern tüketicinin belli başlı tüketim davranışlarından sayılabileceğini ifade etmiştir. Fırat ve Schultz (2001) postmodern tüketicilerle ilgili yaptıkları araştırmalarında aşağıdaki özellikleri dile getirmişlerdir:

- Modern öznenin tersine postmodern tüketici, tek bir kimliği geliştirmek ve ona bağlı kalmaktansa, farklı kimlikleri sergilemeye daha isteklidir.

- Bir önceki madde ile bağlantılı olarak, postmodern tüketici değer ve prensip farklılıklarına karşı daha kabullenici ve açıktır.

- Postmodern tüketici maddi servet ile daha az güdülenirken, anlam yaratan deneyimleri aramaktadır.

- Postmodern tüketici, merkezliğe ya da insanın her şeyin kontrolünün gerekliliğine daha az odaklanır. Aynı zamanda sosyal yaşamın bir insan tasarımı olduğu farkındalığıyla diğer amaçlara alan vermeye daha fazla isteklilik gösterir.

Postmodern tüketiciler pazarlama çalışmalarında daha fazla aktif olma ve kendilerini ifade etmeye eğilimlidirler (Frrat \& Dholakia, 2006) Sosyal medya ise pazarla ilgili içerik oluşturma ve bunu paylaşma konusunda tüketicilerin işlerini kolaylaştırmaktadır (Kaplan \& Haenlein, 2010). Çolak (2018) tarafından üniversite öğrencilerinin postmodernite ve materyalizm bağlamında tüketici profilleri üzerine yapılan bir araştırmada öğrencilerin postmodern tüketici eğilimlerinde (davranışlarında) yaş, cinsiyet, eğitim düzeyi ve gelir düzeyi etkiliyken, medeni durum ve çalışma durumunun etkili bir faktör olmadığı tespit edilmiştir. Araştırmaya katılan öğrencilerin 
postmodern tüketici davranış düzeyleri çoklu benlik ve dağınık özne için 'yüksek/katıllyorum' düzeydeyken, gerçeküstücülük boyutu için 'orta/fikrim yok' düzeyinde olmuştur. Başka bir deyişle, araştırmaya katılan öğrencilerin farklı durum, zaman, yer ve toplumsal çerçevede farklı benlikler sergileme düzeyleri ile hayatı oyun ve bireyleri oyuncu olarak görme, onları nesne olarak değerlendirme ve toplumsal hayatı sürekli değişen bir hayal gibi görme düzeyleri, en üst düzeyde olmasa da, yüksekken, hayat ve hayatın gerçekleştiği çevreyi bir oyun ve hayal olarak görme düzeyleri ise orta düzeyde ortaya çıkmıştır.

\section{Metodoloji}

\section{Araştırmanın Amacı}

Araştırmanın amacı postmodern kişilik özelliklerinin marka sadakatine etkisini incelemektir. Bu amaç doğrultusunda gerçekleştirilen araştırmanın literatürdeki boşluğun doldurulmasına katkı yapması ve mevcut çalışmaları destekleyici nitelikte olması açısından önemli olduğu düşünülmektedir.

\section{Araştırmanın Kapsamı, Kısıtları ve Örneklemi}

Araştırmanın evrenini Bolu Abant İzzet Baysal Üniversitesi'nde 2019-2020 Eğitim-Öğretim yılında öğrenim görmekte olan öğrenciler oluşturmaktadır. Veriler 308 kişiden tesadüfi olmayan örnekleme yöntemlerinden biri olan kolayda örnekleme yöntemi ile elde edilmiştir. Araştırmanın en önemli kısitını, zaman ve maddi kaynak yetersizliğinden dolayı uygulamanın sadece Bolu Abant İzzet Baysal Üniversitesi öğrencileri üzerinde yapılması oluşturmaktadır.

\section{Araştırma Modeli ve Hipotezler}

Araştırmada, çoklu benlik, dağınık özne, gerçeküstücülük, marka sadakati olmak üzere dört değişken yer almaktadır. Araştırmanın amacı ve incelenen literatürden yola çıkılarak oluşturulan araştırma modeli ve hipotezleri Şekil 1 'de gösterilmektedir. 


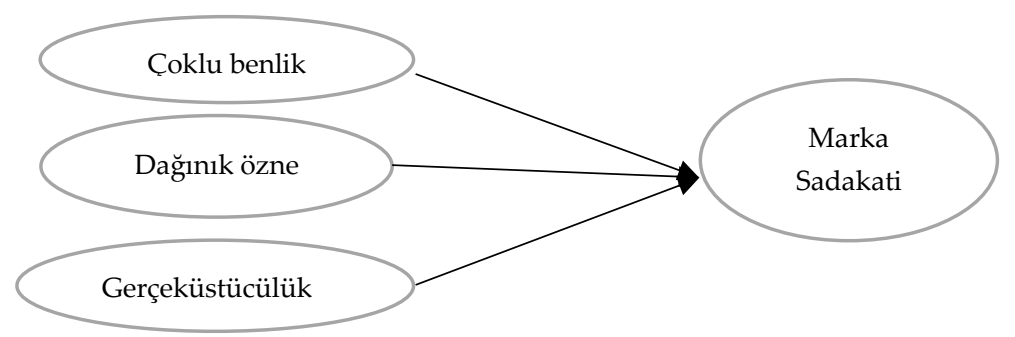

Şekil 1. Araştırma Modeli

\section{Araştırmanın Hipotezleri}

Araştırmanın amacı doğrultusunda hipotezler aşağıdaki gibi kurulmuştur:

- H1: Çoklu Benlik boyutunun marka sadakati üzerinde anlamlı bir etkisi vardır.

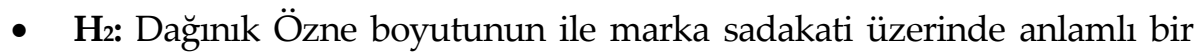
etkisi vardır.

- $\quad H_{3}$ : Gerçeküstücülük boyutunun marka sadakati üzerinde anlamlı bir ilişki vardır.

\section{Verilerin Toplanması ve Analizi}

Araştırma kapsamında veriler 2019 Ekim ayında yüz yüze anket tekniği ile toplanmıştır. Nihai araştırmaya geçilmeden önce 30 katılımc ile ön araştırma yapılmış ve ankette yer alan ifadeler ile ilgili herhangi bir sorun tespit edilmemesi üzerine nihai araştırmaya geçilmiştir. Araştırma sonunda eksik ya da hatalı doldurulduğu tespit edilen anketler çıkarıldıktan sonra 308 anket analize tabi tutulmuştur. Anket 5'li Likert tipi (1-Kesinlikle Katılmiyorum,..., 5-Kesinlikle Katılıyorum) olarak ve toplam 21 ifadeden oluşmaktadır. Ankette iki farklı ölçek kullanılmıştır. Ankette Firat ve Shultz (2001) tarafından geliştirilen ve Çolak ve Görkem (2019) tarafından Türkçeye uyarlanan, geçerliliği ve güvenilirliği test edilen Postmodern Tüketici Ölçeği kullanılmıştır. Marka Sadakati Ölçeği olarak ise Valence ve diğerleri (1988) tarafından geliştirilen, Çakır ve Arslan (2016) ile Yapraklı vd., (2017) tarafından Türkiye'de uygulanan geçerliliği ve güvenilirliği test edilen ölçek kullanılmıştır. Postmodern Tüketici Ölçeğinin alt boyutlarının adlandırıl- 
ması orijinal çalışmadan olduğu gibi alınmıştır. Elde edilen veriler AMOS 20 Paket programı ile analiz edilmiştir. Araştırmada kullanılan ölçeklerin güvenirlilikleri Cronbach Alfa katsayı yöntemi ile test edilmiştir. Araştırmada boyutların doğrulanmasında doğrulayıcı faktör analizi (DFA) kullanılmıştır. Daha sonra, yapısal eşitlik modeli yöntemi ile değişkenler arasındaki etkileşim analiz edilmiştir. Bu bağlamda çoklu benlik, dağınık özne, gerçeküstücülük bağımsız değişken, marka sadakati bağımlı değişken olarak alınmıştır.

\section{Bulgular}

Bu bölümde araştırma kapsamında elde edilen veriler ile yapılan analizler ve bulgulara yönelik bilgiler yer almaktadır.

Tablo 1. Tüketicilerin Demografik Özellikleri

\begin{tabular}{|c|c|c|c|c|c|}
\hline Cinsiyet & $\mathbf{F}$ & $\%$ & Aylık Ort. Kişisel Gelir & $\mathbf{F}$ & $\%$ \\
\hline Kadın & 215 & 69,8 & 500 TL ve Altı & 169 & 54,9 \\
\hline Erkek & 99 & 30,2 & $501 \mathrm{TL}-750 \mathrm{TL}$ & 81 & 26,3 \\
\hline Aile Ort. Geliri & $\mathbf{F}$ & $\%$ & $751 \mathrm{TL}-1000 \mathrm{TL}$ & 36 & 11,7 \\
\hline 2020 ve Altı & 64 & 20,8 & 1001 TL-1250 TL & 10 & 3,2 \\
\hline 2021 TL-3000 TL & 102 & 33,1 & 1251 TL ve Üstü & 12 & 3,9 \\
\hline 3001 TL-4000 TL & 62 & 20,1 & En Uzun Yaşanılan Yerleşim Yeri & $\mathbf{F} \%$ & \\
\hline 4001 TL-5000 TL & 47 & 15,3 & Köy & 34 & 11,0 \\
\hline 5001 TL ve Üzeri & 33 & 10,7 & İlçe & 59 & 19,2 \\
\hline Alışverişinizi nerede yaparsınız? & $\mathbf{F}$ & $\%$ & Şehir & 84 & 27,3 \\
\hline Alışveriş merkezi & 132 & 42,9 & Büyükşehir & 131 & 42,5 \\
\hline Cadde mağazaları & 140 & 45,5 & Satın alma kararınızı kim etkiler? & $\mathbf{F}$ & $\%$ \\
\hline Online alışveriş & 29 & 9,4 & Arkadaş & 133 & 43,3 \\
\hline Mobil Uygulama & 2 & 0,6 & Aile üyesi & 78 & 25,3 \\
\hline Diğer & 5 & 1,6 & Sosyal medya ünlüleri & 26 & 8,4 \\
\hline Alışverişe kiminle çıkarsınız? & $\mathbf{F}$ & $\%$ & Geleneksel ünlüler & 4 & 1,3 \\
\hline Yalnız & 72 & 23,4 & TV reklamları & 19 & 6,2 \\
\hline Aileden biriyle & 84 & 27,3 & Diğer & 48 & 15,6 \\
\hline Arkadaşımla & 143 & 46,4 & $\begin{array}{l}\text { Alışverişlerinizi ne sıklıkla } \\
\text { yaparsınız? }\end{array}$ & $\mathbf{F}$ & $\%$ \\
\hline Diğer & 9 & 2,9 & Haftada bir & 53 & 17,2 \\
\hline Satın alma kararınızı ne etkiler? & $\mathbf{F}$ & $\%$ & İki haftada bir & 52 & 16,9 \\
\hline Ürünün fiyatı & 129 & 41,9 & Ayda bir & 32 & 10,4 \\
\hline Ürünün kalitesi & 96 & 31,2 & İhtiyacım olduğunda & 169 & 54,9 \\
\hline Ürünün markası & 14 & 4,5 & Diğer & 2 & 0,6 \\
\hline Ürünün tasarımı & 63 & 20,5 & & & \\
\hline Diğer & 6 & 1,9 & & & \\
\hline Toplam & 308 & 100 & Toplam & 308 & 100 \\
\hline
\end{tabular}


Tablo 1'de katılımcların demografik özelliklerine ve alışveriş alışkanlıklarına yönelik bilgiler bulunmaktadır. Tablo incelendiğinde araştırmaya katılan 308 katılımcının yaklaşık \%70'nin bayan olduğu, büyük çoğunluğun uzun süre büyükşehirlerde yaşadığı, aylık ortalama kişisel geliri 500 TL ve altında olanların araştırmada çoğunlukta olduğu, ailelerin ortalama aylık gelirleri 2021 TL-3000 TL arasında olanların yine çoğunlukta olduğu görülmektedir. Katılımcıların, alışveriş alışkanlıklarına bakıldığında ise büyük çoğunluğun ihtiyacı olması durumunda alışveriş yaptığı, yine benzer şekilde alışveriş için alışveriş merkezlerini ve cadde mağazalarını tercih ettiği, alışverişe arkadaşı ile birlikte çıkanların çoğunlukta olduğu ve alışveriş kararlarında arkadaşların etkisinin daha büyük olduğu anlaşılmaktadır. Son olarak katılımcların alışveriş kararlarında ürünün fiyatının büyük önem taşıdığ tablodan anlaşılmaktadır.

Tablo 2. Araştırmada Yer Alan Ölçeklerin Güvenirlilik Analizleri

\begin{tabular}{lll}
\hline Ölçekler & Değişken sayısı & Cronbach Alfa \\
\hline Çoklu Benlik & 4 & 0,747 \\
\hline Dağınık Özne & 4 & 0,710 \\
\hline Gerçeküstücülük & 4 & 0,700 \\
\hline Marka Sadakati & 9 & 0,900 \\
\hline
\end{tabular}

Cronbach Alpha değerinin 0,70 ve üzerinde olması ölçeklerin güvenilirliğinin kabul edilebilir olması anlamına gelmektedir (Nunnally, 1978). Uygulanan normallik testine göre boyutların tamamının normal dağılım gösterdiği belirlenmiştir.

Tablo 3'te açımlayıcı faktör analizi sonucu elde edilen 4 faktöre ait maddeler ve bu maddelere uygun adlandırılmalar yer almaktadır. Faktör isimlendirmelerinde ölçeklerin özgün faktör ifadeleri dikkate alınmıştır. 
Tablo 3. Faktörlerin Adlandırılması

\begin{tabular}{ll}
\hline $\begin{array}{l}\text { Madde } \\
\text { No }\end{array}$ & Faktörler \\
\hline Birinci Faktör: Çoklu Benlik \\
\hline p1 & $\begin{array}{l}\text { Her zaman aynı kişiliği sergilemektense, farklı durumlarda farklı kişilikler ser- } \\
\text { gilemekten hoşlanırım. }\end{array}$ \\
\hline p2 & $\begin{array}{l}\text { İçinde bulunulan toplumsal duruma göre farklı bir imaj sergileyebilme becerisi } \\
\text { önemlidir. }\end{array}$ \\
\hline p3 & Farklı durumlarda farklı bir insan olurum. \\
\hline p4 & Bulunduğum her ortama uymak için imajımı değiştirmekten hoşlanırım. \\
\hline İkinci Faktör: Dağınık Özne \\
\hline p5 & $\begin{array}{l}\text { Eğlence parkları (Disneyland, Vialand vb.) çevremizin birer kopyası değil çevremiz } \\
\text { eğlence parklarının birer kopyasıdır. }\end{array}$ \\
\hline p6 & Şehirlerimiz, birer eğlence parkından farklı değil. \\
\hline p7 & Pembe diziler hayatın kopyası değil, hayat pembe dizilerin kopyasıdır. \\
\hline p8 & Bir hayal dünyasında yaşama konusunda bir problemim olmazdı. \\
\hline Üçüncü Faktör: Gerçeküstücülük \\
\hline p9 & $\begin{array}{l}\text { Toplumsal varoluşumuz sürekli değişen bir hayal gibi sonuçta, bu durumu inkar } \\
\text { etmek yerine yaşamalıyız. }\end{array}$ \\
\hline p10 & İnsanlar nesneler gibidir, çünkü onlar da pazarlanabilir. \\
\hline p11 & $\begin{array}{l}\text { Hayat oyunlardan ibarettir; önemli olan insanların bu oyunların farkında olması ve } \\
\text { aktif birer oyuncu haline gelebilmesidir. }\end{array}$ \\
\hline p12 & İnsanları birer nesne olarak değerlendirebiliriz. \\
\hline Marka Sadakati \\
\hline s1 & Sadık müşterisi olduğum markalarım vardır. \\
\hline s2 & Diğer markalara göre bu markaları daha yakından takip ederim \\
\hline s3 & Bağlı olduğum markayla ilgili diğer insanlara olumlu şeyler söylerim \\
\hline s4 & Benden tavsiye isteyenlere markalarımı öneririm \\
\hline s5 & Arkadaşlarımı ve akrabalarımı markalarımı kullanmaları için teşvik ederim \\
\hline s6 & $\begin{array}{l}\text { Benim için bu markaları satın almak, diğer markaları satın almaya göre daha önem- } \\
\text { lidir }\end{array}$ \\
\hline s7 & Daima aynı markaları kullanırım. Çünkü bu markaları gerçekten çok seviyorum \\
\hline s8 & Ileride de bu markaları kullanmaya devam edeceğim. \\
\hline & Alış veriş yapmaya karar verdiğimde hep aynı markalar ilk tercihimdir. \\
\hline
\end{tabular}

Tablo 4. Ölçeklerin Düzeltilmiş Tek Boyutlu Doğrulayıcı Faktör Analizi

\begin{tabular}{lcccccc}
\hline $\begin{array}{l}\text { Uyum } \\
\text { ölçüleri }\end{array}$ & $\begin{array}{l}\text { İyi uyum } \\
\text { uyum }\end{array}$ & $\begin{array}{c}\text { Kabul } \\
\text { edilebilir } \\
\text { uyum }\end{array}$ & Çoklu Benlik & $\begin{array}{c}\text { Dağınık } \\
\text { Özne }\end{array}$ & $\begin{array}{c}\text { Gerçeküs- } \\
\text { tücülük }\end{array}$ & $\begin{array}{l}\text { Marka } \\
\text { Sadakati }\end{array}$ \\
\hline $\begin{array}{l}\chi 2 / \mathrm{df}(\mathrm{CMIN} \\
\mathrm{DF} / \mathrm{df})\end{array}$ & $\leq 3$ & $\leq 4-5$ & 2,716 & 1,578 & 3,945 & 0,729 \\
\hline GFI & $\geq 0,90$ & $0,89-0,85$ & 0,991 & 0,998 & 1,000 & 0,998 \\
\hline CFI & $\geq 0,97$ & $\geq 0,95, \geq 0,90$ & 0,989 & 0,999 & 0,999 & 1,000 \\
\hline RMSEA & $\leq 0,05$ & $0,06-0,08$ & 0,075 & 0,010 & 0,070 & 0,000 \\
\hline
\end{tabular}


Ölçeklerin uyum değerlerinin sağlanması için beta değeri düşük olan ifadeler modelden çıkarılmış ve ayrıca kovaryans ilişkisi kurulmuştur. Modelde P7, P10, S6,S7, S9'un beta değeri düşük olduğundan modelden çıkarılmıştır. Ölçeği düzeltilmiş DFA uyum değerleri Tablo 4'de verilmiştir. Çoklu benliğin $\chi 2$ : Ki kare(CMIN) df (Degrees of Freedom): 2,716; RMSEA (Root Mean Square Error of Approximation); 0,075; CFI (Comparative Fit Index):0,989; GFI (Goodness of Fit Index): 0,991. Dağınık öznenin $\chi 2 / d f(C M I N /$ df ): 1,578; RMSEA; 0,010; CFI:0,999; GFI: 0,998, NFI: 0,989. Gerçeküstücülüğün $\chi 2 / \mathrm{df}(\mathrm{CMIN} / \mathrm{df}$ ): 3,945; RMSEA; 0,070; CFI:0,999, GFI: 1,000. Marka Sadakatinin $\chi 2 / \mathrm{df}(\mathrm{CMIN} / \mathrm{df}$ ): 0,729; RMSEA; 0,000; CFI:1,00; GFI: 0,998 değerlerini aldığı görülmektedir. Bu değerlere göre, uyum iyiliği indekslerine bakıldığında tüm uyum ölçülerinin kabul edilebilir ve iyi uyum sınırları içinde olduğu görülmektedir.

Tablo 5. Değişkenlere Ait Standart Sapma Değerleri

\begin{tabular}{lc}
\hline Değişkenler & Standart sapma \\
\hline Çoklu benlik & 0,9013 \\
\hline Dağınık özne & 0,8344 \\
\hline Gerçeküstücülük & 0,8478 \\
\hline Marka Sadakati & 0,8657 \\
\hline
\end{tabular}

Tablo 5'te değişkenlere ait standart sağma değerleri yer almaktadır. Araştırmada çoklu benliğin standart sapması 0,9013, dağınık öznenin 0,8344, gerçeküstücülüğün 0,8478, marka sadakatinin 0,8657 olarak bulunmuştur.

Tablo 6. Model Uyum Değerleri

\begin{tabular}{lccc}
\hline Uyum Ölçüleri & İyi Uyum & Kabul Edilebilir Uyum & Yapısal Model \\
\hline$\chi 2 / \mathrm{df}(\mathrm{CMIN} / \mathrm{df})$ & $\leq 3, \leq 5$ & $\leq 4-5$ & 2,409 \\
\hline GFI & $\geq 0,90$ & $0,89-0,85$ & 0,915 \\
\hline CFI & $\geq 0,97$ & $\geq 0,95, \geq 0,90$ & 0,919 \\
\hline RMSEA & $\leq 0,05$ & $0,06-0,08$ & 0,068 \\
\hline
\end{tabular}

Kaynak: Meydan ve Şeşen, 2011

Ölçeklerin uyum değerlerinin sağlanması için beta değeri düşük olan ifadelerin modelden çıkarılması ve kovaryans ilişkilerinin kurulmasından sonra Tablo 6'daki sonuçlara ulaşılmıştır. $\chi 2$ : Ki kare (CMIN) - df (Degrees of Freedom): 2,409; GFI (Goodness of Fit Index): 0,915; CFI (Comparative Fit Index): 0,919; RMSEA (Root Mean Square Error of Approximation); 
0,068'dir. Değerlere göre, uyum iyiliği indekslerine bakıldığında RMSEA dışında tüm uyum ölçülerinin iyi uyum sınırları içinde olduğu RMSEA değerinin ise kabul edilebilir uyum sınırları içinde olduğu tespit edilmiştir.

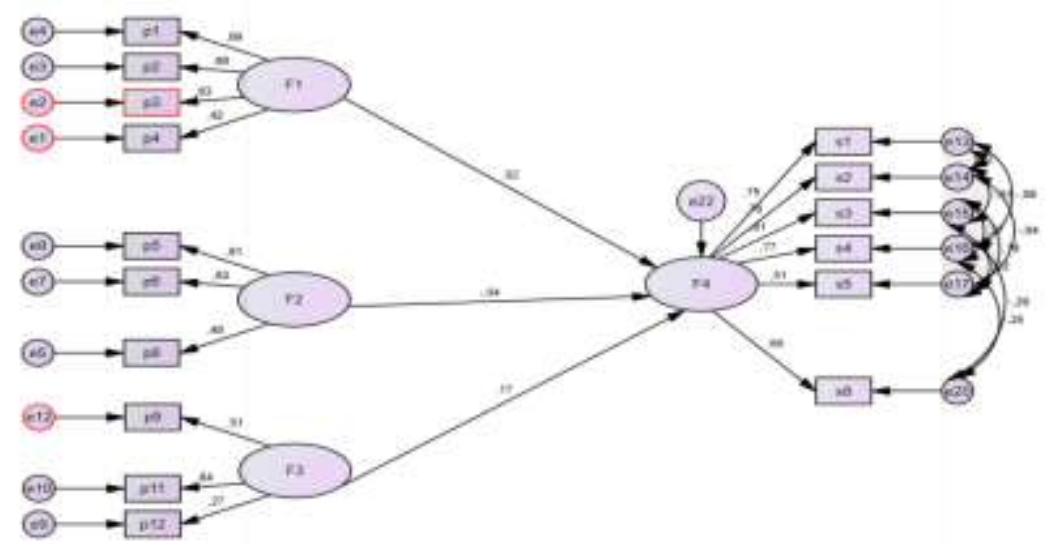

Şekil 2. Çoklu Benlik, Dağınık Özne, Gerçeküstücülü̈̆̈̈n Marka Sadakati Üzerindeki Etkisi

${ }^{*} F 1=$ çoklu benlik, F2= dağınık özne, F3=gerçeküstücülük, F4=marka sadakati

Şekil 2'de, yapısal modelin uyum değerlerinin sağlanması için beta değeri düşük olan ifadeler modelden çıarılmış ve ayrıca kovaryans ilişkileri kurulmuştur.

Tablo 7. Araştırma Modeli Hipotez Sonuçları

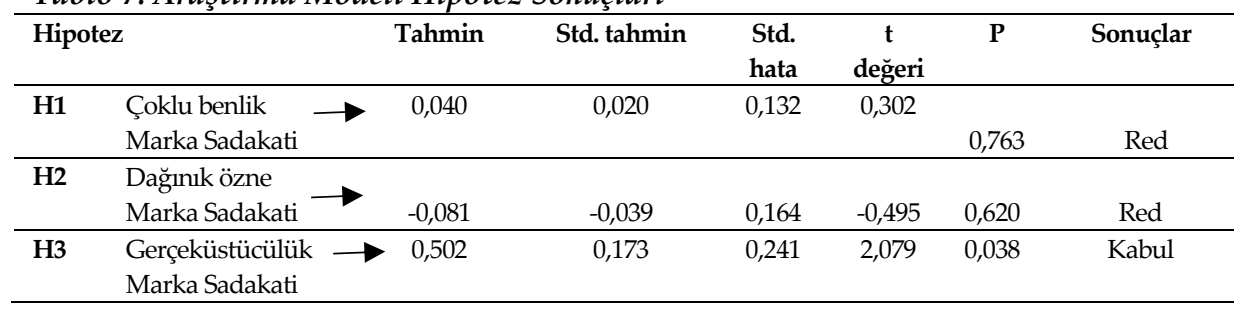

Tablo 7'de yer alan sonuçlara göre, çoklu benlik boyutu ile Marka Sadakati boyutu arasindaki standardize regresyon katsayısı $\beta: 0,020, \mathrm{t}: 0,302$, $\mathrm{p}: 0,763$ ve $\mathrm{p}$ anlamll1ı düzeyi $\mathrm{p}>0,05$ 'dir. Bu sonuca göre $\mathrm{H}_{1}$ hipotezi red edilmiştir. Çoklu benliğin marka sadakati üzerinde anlamlı bir etkisi olduğu bulunmamıştır. 
Dağınık özne boyutu ile Marka Sadakati boyutu arasındaki standardize regresyon katsayısı $\beta:-0,039, \mathrm{t}:-0,495, \mathrm{p}: 0,620$ ve $\mathrm{p}$ anlamlılık düzeyi $\mathrm{p}>0,05$ 'dir. Bu sonuca göre $\mathrm{H}_{2}$ hipotezi red edilmiştir. Dağınık öznenin marka sadakati üzerinde anlamlı bir etkisinin bulunmadığı belirlenmiştir.

Gerçeküstücülük boyutu ile Marka Sadakati boyutu arasındaki standardize regresyon katsayısı $\beta: 0,173, \mathrm{t}: 2,079$, p: 0,038 ve $\mathrm{p}$ anlamlılık düzeyi $\mathrm{p}<0,05)^{\prime}$ dir. Bu sonuca göre $\mathrm{H}_{3}$ hipotezi kabul edilmiştir. Gerçeküstücülük boyutunun marka sadakati boyutu üzerinde zayıf ve anlaml bir etkisinin olduğu sonucuna ulaşılmıştır.

\section{Sonuç ve Öneriler}

Postmodernizm ile birlikte günlük hayatın en önemli aktivitelerinden biri haline gelen tüketim şüphesiz bireylerin çok çeşitli özellikleri nedeniyle her bireyde farklı bir şekilde kendini göstermektedir. Bireylerin gün içinde bulundukları ortam ve koşullara göre farklı kişiliklere bürünmeleri, tüketilen nesnelerin içerik ve öneminin gözden düşüp sembolik değerlerinin öne çıtığı, birbiri ile neredeyse hiçbir ilgisi bulunmayan nesne ya da olaylarla sıkça karşılaşılması marka ve firmaların işini giderek zorlaştırmaktadır. Bütün bu karmaşa/düzensizlik içinde tüketicileri sadık birer müşteri haline getirmek, pazar paylarını korumak, satışlarını arttırmak konusunda her zamankinden daha fazla çalışmaları zorunlu hale gelmiştir.

Postmodern tüketici özelliklerinin marka sadakatine etkisini incelemek amacıyla yapılan araştırma kapsamında tüketicilerin çoğunlukla arkadaşları ile çıtıkları alışverişlerde satın alma kararlarını ürünün fiyatının ve arkadaşların etkilediği sonucuna ulaşılmıştır. Katılımcıların büyük çoğunluğunun alışverişlerini alışveriş merkezleri ve cadde mağazalarında yaptığ ulaşılan bir diğer sonuç olmuştur. Bu sonuçlar günümüz tüketicileri için arkadaşların ne kadar önemli olduğunu göstermesi açısından önemlidir. Burada Kayaman ve Armutlu (2003)'nun çalı̧̧malarında, ürünlerin pazardaki başarısının bireyler arasında oluşan sosyal bağların gelişmesi ve güçlendirilmesine yaptıkları katkıdan geçtiğini vurguladıkları gibi, marka ve firmaların da arkadaş grupları üzerinden pazarlama iletişimi çalışmalarını planlamaları ve yine arkadaş temalı iletişim çalışmaları yapmalarının çalışmalarının başarısını olumlu yönde etkileyeceği düşünülmektedir. 
Araştırma kapsamında çoklu benlik, dağınık özne ve gerçeküstücülük boyutları üzerinden tüketicilerin postmodern özellikleri tanımlanmıştır. Postmodern tüketici özellikleri olarak ifade edilen bu üç boyutun tüketicilerin marka sadakati davranışları üzerindeki etkisi ile ilgili olarak sadece gerçeküstücülük boyutunun marka sadakati boyutu üzerinde etkili olduğu sonucuna ulaşılmıştır. Diğer özellikler olan çoklu benlik ve dağınık özne boyutlarının ise marka sadakati boyutu üzerinde etkisi tespit edilememiştir. Bu sonuç, tüketicilerin markaya bağlllıklarında markaların ya da ürünlerin yararının, dayanıklılığının, fonksiyonelliğinin vb. somut özelliklerinden ziyade medya aracllı̆̆ıla sürekli vurgulanan simgesel değerlerin ve mesajların etkili olduğu ve bu değerler üzerinden marka ve ürünlerin tercih edildiği günümüz tüketim alışkanlıkları ile örtüşmektedir. Çünkü simgesel çağrışımların ve imajların istilası içerisindeki gündelik hayat bireyin anlık deneyimleri ile değer kazanmaktadır. Ürünün kullanım değerinin dışında yaratılan imajlar ve ön plana çkarılan anlamlar ile ürünün tüketicisinin kişiliğine artı değer kattığına inanılmaktadır (Kezer, 2012). Postmodern tüketicilerin, gerçekliğe kıyasla, simülasyonlardan daha fazla haz aldığının bilinmesi (Çolak ve Görkem, 2019) ve marka ve firmaların marka sadakati oluşturma sürecinde gerek markalarının gerekse ürünlerinin kullanım değeri bir yana markanın hissettireceği, yakışıklılık, güzellik, çekicilik, güç, zenginlik, farklılık, saygınlık gibi soyut unsurlara odaklanmalarının daha etkili olacağı düşünülmektedir. Nitekim Firat ve Venkatesh (1995) tüketicilerin sadık kalacağı şeyler olarak markaların değil, özellikle tüketirken ürettikleri görseller ve semboller olduğunu belirtmişlerdir. Bu doğrultuda tüketicilerin üretim süreçlerine dâhil edilmesi ve üretim sürecine katılmaları nedeniyle bir takım sembolik anlamlar çıkartmalarının sağlanması markaya bağlllıklarında etkili olabilecektir.

Sonuç olarak tüketicilerin postmodern özelliklerinin onların demografik özellikleri, maruz kaldıkları medya içerikleri içinde yetiştikleri sosyal ve kültürel çevre ile ilişkili olduğu unutulmamalıdır. Ancak günümüz tüketicilerinin önceki tüketicilerden daha postmodern yaşadığı da bir gerçektir. Bu nedenle marka ve firmaların postmodern tüketicileri anlayabilmek için öncelikle kendilerinin de bu anlayışın özelliklerine hakim olmaları ve marka ve ürünlerinin pazarlama iletişim çalışmalarını bu anlayışla biçimlendirmeleri gerekmektedir. 


\section{EXTENDED ABSTRACT}

\section{The Effect of Postmodern Consumer Characteristics on Brand Loyalty \\ Niyazi Gümüş - Ebru Onurlubaş \\ Bolu Abant Izzet Baysal University - Trakya University}

Consumption has been one of the primary activities of human beings since the day it existed. Because human beings have to consume their vital activities. The developments in production technologies over time have revealed mass production and a great abundance era has begun to occur in every field. Mass production in production, improvements in income, information and communication technologies, as well as facilitation and acceleration of communication and interaction brought along changes in the sense loaded on the concept of consumption. Individuals are now in a race to consume more and faster in order to keep up with the most changing conditions. This fast consumption race made individuals pay more attention to their symbolic values than the content of the products they consume. Therefore, it has become more important where, how, with whom and how much it consumes for individuals. Undoubtedly, it should not be forgotten that the rapidly shared pages of social media channels, which are expressed as new media, have an effect on the change of the consumption patterns of individuals. This symbolic-weighted consumption of consumers is considered as a reflection of postmodernism. In general, it is observed that the meaning that individuals attribute to consumption changes today and the purchasing decisions of consumers are shaped by the effect of postmodern culture.

Within the scope of the research, the data were collected in October 2019 with a face-to-face survey technique. Before proceeding with the final research, 30 participants were preliminary research and the final research was started when no problem was detected regarding the statements in the questionnaire. At the end of the research, 308 questionnaires were subjected to analysis after removing the questionnaires that were found to be missing or incorrectly filled. The survey consists of 5 Likert type (1-Strongly Disagree,..., 5-Strongly Agree) and a total of 21 statements. Two different scales 
were used in the survey. The Postmodern Consumer Scale developed by Firat and Shultz (2001) and adapted to Turkish by Çolak and Görkem (2019) was used in the survey. Brand Loyalty Scale as the Valence et al (1988) developed by Cakir and Armstrong (2015) with a leafy et al., (2017) was used by the scale practiced in Turkey. Naming the sub-dimensions of the Postmodern Consumer Scale was taken from the original study. The data obtained were analyzed with the AMOS 20 Package program. The reliability of the scales used in the study was tested by Cronbach Alpha coefficient method. Confirmatory factor analysis (CFA) was used in the study to verify the dimensions. Then, the interaction between variables was analyzed by the structural equation model method. In this context, multiple self, scattered subject, surrealism are taken as independent variable, brand loyalty dependent variable.

Within the scope of the research conducted to examine the effect of postmodern consumer properties on brand loyalty, it was concluded that the price of the product and the friends affected the purchasing decisions of the consumers mostly with their friends. Another result is that the majority of the participants did their shopping in shopping malls and street stores. These results are important to show how important friends are to today's consumers. Here, Kayaman and Armutlu (2003) emphasized that the success of the products in the market has contributed to the development and strengthening of social ties between individuals, as well as the success of the efforts of brands and companies to plan marketing communication studies and also to make friend-based communication studies. It is thought to affect.

Within the scope of the research, the postmodern features of consumers are defined through the dimensions of multiple self, scattered subject and surrealism. Concerning the impact of these three dimensions, which are expressed as postmodern consumer characteristics, on consumers' brand loyalty behavior, it was concluded that only the surrealism dimension was effective on the brand loyalty dimension. The effects of multiple self and scattered subject dimensions, which are other features, on the brand loyalty dimension could not be determined. This result is the benefit, durability, functionality, etc. of brands or products in the loyalty of consumers to the brand. It coincides with today's consumption habits in which symbolic values and messages, which are constantly emphasized through the media rather than their concrete features, are influential and brands and products 
are preferred over these values. Because everyday life in the invasion of symbolic connotations and images gains value with the instantaneous experiences of the individual. It is believed that the product adds value to the personality of the consumer with the images created outside of the product's use value and the meanings brought to the fore (Kezer, 2012).

\section{Kaynakça / References}

Azizağaoğlu, A. ve Altunışık, R. (2012). Postmodernizm, sembolik tüketim ve marka. Tüketici ve Tüketim Araştırmaları Dergisi. 4, 33-50.

Baudrillard, J. (2017). Tüketim toplumu, söylenceleri, yapıları. (Çev: N. Tutal ve F. Keskin), Ayrıntı Yayınları: İstanbul.

Berner, A. ve Tonder, C. V. (2003). The postmodern consumer: Implications of changing customer expectations for organisation development in service organisations. Journal of Industrial Psychology, 29 (3), 1-10

Cengiz, H. (2014). Gönüllü sade yaşam davranışının ölüm tüketimi davranışına yönelik tutumlar üzerine etkisi: Türk ve Amerikan kültürleri arasinda bir karşılaştırma. Doktora Tezi. Eskişehir Osmangazi Üniversitesi, Sosyal Bilimler Enstitüsü İşletme Anabilim Dalı, Eskişehir.

Çakır, A. ve Arslan, B. (2016). Kurumların uyguladıkları sosyal sorumluluk projelerinin tüketicilerin marka sadakati üzerine etkileri: Otomobil markaları üzerine bir araştırma. СBÜ Sosyal Bilimler Dergisi, 14(2), 437452.

Çolak, E. (2018). Postmodernite ve materyalizm bağlamında genç tüketici profili: Üniversite öğrencileri üzerine bir alan araştırması. Yüksek Lisans Tezi Maltepe Üniversitesi Sosyal Bilimler Enstitüsü, Halka İlişkiler ve Tanıtım Anabilim Dalı, İstanbul.

Çolak, E. ve Görkem, Ş. Y. (2018). Postmodernite ve materyalizm bağlamında genç tüketici profili: üniversite öğrencileri üzerine bir alan araştırması. Maltepe Üniversitesi Illetişim Fakültesi Dergisi, 5(2), 176-196.

Eroğlu, F. (2016). Kompulsif satın alma: Kişisel faktörler, postmodern tüketim şekilleri ve reklama karşı tutumun rolüne yönelik bir araştırma. Balıkesir Universitesi Sosyal Bilimler Enstitüsü Dergisi, 19(35), 253-282.

Firat, A. ve Venkatesh, A. (1993). Postmodernity: The age of marketing. International Journal of Marketing, 10, 227-249.

Firat, A. ve Venkatesh, A. (1995). Liberatory postmodernism and the reenchantment of consumption. Journal of Consumer Research, 22, 239-267. 
Firat, A. F. ve Dholokia, N.(2006). Theoretical and philosophical implications of postmodern debates: Some challenges to modern marketing. Marketing Theory, 6(2), 123-162

Firat, A. F., Dholokia, N. ve Venkatesh, A. (1995). Marketing in a Postmodern world. European Journal of Marketing, 29(1), 40-56.

Firat, A. F. ve Shultz, C. (2001). Preliminary metric investigations into the nature of the postmodern consumer. Marketing Letters, 12(2), 189-203.

Gümüş, N. (2018). Tüketim çağı. Ankara: Gazi Kitabevi

Hamouda, M. ve Gharbi, A. (2013). The postmodern consumer: An identity constructor?. International Journal of Marketing Studies, 5(2), 41-49

Kaplan, A.M. ve Haenlein, M.,(2010). Users of the world, unite! The challenges and opportunities of social media. Business Horizonn, 53, 59-68.

Kayaman, R. ve Armutlu, C. E. (2003). Post-modern tüketici davranışının pazar bölümleme kavramına etkileri: Postmodern klanlar. Gazi Üniversitesi, Ticaret ve Turizm Ĕ̆itim Fakültesi Dergisi, 1, 1-18.

Kazancioğlu, Ö. (2019). Modernizmden postmodernizme toplumsal değişme. Yüksek Lisans Tezi, Avrasya Üniversitesi Sosyal Bilimler Enstitüsü İşletme Anabilim Dalı, Trabzon.

Kırılmaz, H. ve Ayparçası, F. (2016). Modernizm ve postmodernizm süreçlerinin tüketim kültürüne yansımaları. İnsan \& İnsan, 3(8), 32-58

Kezer, P. (2012). Postmodern tüketicinin değişen satın alma davranışı: İçgüdüsel alı̧veriş. Yayınlanmamış yüksek Lisans Tezi, Ege Üniversitesi Sosyal Bilimler Enstitüsü Halkla İlişkiler Ve Tanıtım Anabilim Dalı, İzmir.

Meydan, C. H. ve Şeşen, H. (2011). Yapısal eşitlik modellemesi AMOS uygulamaları (1 ed.). Ankara: Detay Yayınevi.

Nunnally, J. C. (1978). Psychometric theory (2nd ed.). New York, NY: McGrawHill.

Odabaşı, Y. (2004). Postmodern pazarlama tüketim ve tüketici. İstanbul: MediaCat Kitapları.

Özbölük, T. (2015). Postmodern tüketici kabileleri ve sanal topluluklar: netnografik bir araştırma. Doktora Tezi. Erciyes Üniversitesi Sosyal Bilimler Enstitüsü, Kayseri.

Şaylan, G. (2009). Postmodernizm. İstanbul: İmge Kitabevi.

Tekeli, İ. (2017). Postmodernizm tartışmaları üzerine düşünceler. Düşünme Dergisi, 10, 8-19.

Teschl, M. (2007). What does it mean to be decentered? Review of Social Economy, 2, 195-201. 
Yapraklı, Ş., Noksan, E. ve Ünalan, M. (2017). Tüketicilerin sosyal sorumluluk projelerine yönelik genel tutumlarının marka sadakati ve satın alma niyeti üzerindeki etkisi. МСВÜ Sosyal Bilimler Dergisi 15(4), 133-154.

Kaynakça Bilgisi / Citation Information

Gümüş, N. ve Onurlubaş, E. (2020). Postmodern tüketici özelliklerinin marka sadakatine etkisi. OPUS-Uluslararası Toplum Araştırmaları Dergisi, 15(21), 405-427. DOI: 10.26466/opus.649771 